\title{
Ward Management and Empowerment of Society Through the Development of Potential Tourism in the South Singkawang Environment
}

\author{
Nindy Citroresmi P ${ }^{1}$, Fitri ${ }^{2}$, Eti Sunarsih ${ }^{3}$, Eka Murdani ${ }^{4}$, Nurul Husna ${ }^{5}$, Rien Anitra ${ }^{6}$ \\ STKIP Singkawang ${ }^{1,2,3,4,5,6}$ \\ nindy.citroresmi@gmail.com ${ }^{1}$, fitri_djayadi@yahoo.co.id ${ }^{2}$, etisunarsih89@gmail.com ${ }^{3}$, \\ ekamurdani@gmail.com ${ }^{4}$, nuna_husna@ymail.com.com ${ }^{5}$, anitrarien@gmail.com6
}

\section{Keywords :}

Realty Tours, Environmental management.

\begin{abstract}
The activities dedicated to the community for environmental management and empowerment of communities through the development of tourism potential are implemented by partnering up the PKK suport team, the domestic chairman and the weal community. It aims to give understanding, knowledge, and empower societies to realize a society conscious of a tourist environment that must be maintained and preserved. These environmental management and community empowerment activities are done by methods of speech, discussion, question-andanswer, and demonstration. The benefits of this activity includes; (1) Together people build tourist areas (2) It grows and increases people's sense of and cares for the beautiful of Batu Burung, (3) To encourage people to participate in the preservation of Batu Burung, (4) Assisting the goverment program to promote tourist areas aspecially Batu Burung sites that are still not widely known by outside Sedau society, and (5) provides services that can enable visitors to know where Batu Burung is located and provide products fo garbage diposal on Batu Burung Beach..
\end{abstract}

\section{INTRODUCTION}

West Kalimantan is one of its many attractive tourist attractions, both natural and cultural. West Kalimantan has great potential for the tourism sector, because of its still relatively natural and beautiful natural state. West kalimantan, specialy Singkawang City have 5 sub-distric, 3 of them directly bordering the Natuna Sea, which is the northern Singkawang district, the western outgrowth, and the southern outgrowth. The goverment of the city of Singkawang has devised a layout of space for the southern Singkawang district to serve as a preserve (a nature reserve of forest parks, a mangrove area) and the agricultural areas (tourism areas, the quarry $\mathrm{C}$ materials, the rugged Mountains and lakes of Serantangan). Therefore, the development of tourism potential needs to be developed considering the regional spatial arrangements that have been arranged in such a way by the government. The development of tourism that uses a spatial approach can be seen from the position of tourism objects to other attractions, this is intended to see the potential possessed by tourism objects and the possibility to be developed or developed (Sujali, 1989). Singkawang City, especially in South 
Singkawang Subdistrict, the development of beach tourism can be a superior natural tourism, because many beach tourism objects are formed by the lami process, so they have different characteristics. In the district of South Singkawang itself has five beach attractions, including; Pasir Panjang Beach, Palm Beach, Tanjung Bajau Beach, Sinka Beach and Batu Burung Beach. But of the five existing beach attractions, one of which is still not managed and developed properly as a tourist attraction, namely Batu Burung Beach. This can be seen from the number of tourists visiting the beach attractions in the City of Singkawang based on the results of interviews with the Village Head of the District of South Singkawang, which is dominated by the Long sand beach, Palm Beach, Tanjung Bajau and Sinka Beach. Therefore we need an effort in order to optimize the Batu Burung Beach tourism object so that it can be known by tourists both domestic and foreign tourists, namely by community empowerment.

Empowerment is a process that emphasizes that people acquire the skills, knowledge, and power that sufficiently influences their lives and the lives of others who become their concerns (Suharto, 2010). Ideally empowerment must include community participation, increase community capacity and foster social and cultural potential to achieve community independence (Prihartono, 2013). Community empowerment efforts can be assessed through 3 aspects including; (1) Enabiling is to create an atmosphere of potential community to develop. Empowerment is an effort to build power by encouraging, motivating and raising awareness of the potential of the community and efforts to develop it; (2) Empowering, that is, strengthening the potential of the community through concrete steps concerning the provision of various inputs and opening up in various opportunities that will make the community more empowered; (3) Protecting, namely protecting and defending the interests of the weak community. To increase community participation in the decision making process (Noor, 2011). In addition to empowering the community to manage the environment is also one of the important factors in optimizing tourism objects, STKIP's community service team carries out Environmental Management and Community Empowerment activities through the development of Tourism Potentials in the Sedau Environment in south Singkawang district.

\section{Research Problem:}

Based on the above exposure, the problem can be formulated as follows :

1. How to empower the community in optimizing the tourism potential of Batu Burung Beach in South Singkawang District?

2. How is the environmental management of Batu Burung Beach attractions in Sedau, South Singkawang District?

\section{Purpose of Activity}

This activity aims to:

1. Empower the community in optimizing the tourism potential of Batu Burung Beach, South Singkawang District.

2. Providing socialization about environmental management in Batu Burung Beach tourism object in the area of Sedau, South Singkawang District.

\section{Benefits of Activities}

The benefits gained from this activity are:

1. Together with the community to build a tourist area

2. Fostering and increasing community ownership and concern for the beautiful nature of Batu Burung

3. Invite the community to participate in protecting, maintaining, preserving nature in Batu Burung

4. Helping government programs to promote tourism areas, especially Batu Burung tourist attractions which are still not well known by people outside Sedau.

5. Provide services that can make it easier for visitors to know the location of Batu Burung beach and provide products in the form of landfills at Batu Burung beach 


\section{METHOD}

The service activity method used in this activity is the method of lectures, discussions, questions and answers and demonstrations. The lecture method chosen to deliver material about community empowerment in developing the tourism potential of Batu Burung Beach using 3 aspects of the approach, namely Enabiling, Empaworing and Protecting. The lecture method also utilizes a laptop and LCD to display material through PowerPoint. After delivering the material, it is continued with a question and answer session by the participants. The demonstration method was chosen to provide knowledge and understanding to the community on how to manage the stone bird beach attractions so that they become clean and organized tourism objects and are better known to people outside sedau, which includes making signposts for beach locations (using 3 languages namely Indonesian, Malay, Malay, and Mandarin). The target audience for the activities of Environmental Management and Community Empowerment Through the Development of Tourism Potentials in the Sedau Environment of Singkawang Selatan sub-district are the PKK Mobilizing Team, RT Chairperson, and the Sedau Village Community, totaling 25 people. As for the instructors and resource persons in this activity were the lecturers and students of STKIP Singkawang.

\section{A. Activity Implementation Results}

\section{RESULTS AND DISCUSSIONS}

PPM activities are a form of community service listed in the Tri Dharma of Higher Education. The PPM activity was carried out by involving several lecturers, students, PKK Mobilizers, RT Heads, and the Sedau Urban Community. The form of activities carried out in the form of the socialization of environmental management and community empowerment through the development of the tourism potential of Batu Burung beach in 2018. The socialization of the activities carried out a day, namely on Monday, March 12, 2018 from at 08.30 WIB to finish. There were 25 participants in the activity.

This activity begins with the opening and continued with the presentation of the material. Submission of material is divided into 4 sessions,

1. opening and introduction to community empowerment in developing the tourism potential of Batu Burung Beach by using 3 aspects of the approach namely Enabiling, Empaworing and Protecting;

2. Demonstration of the management of the Batu Burung beach tourism environment

3. questions and answers by participants;

4. cover.

B. Discussion of Results of Implementation of Activities

The results of PPM activities include several components, as follows.

1. Target number of participants;

2. Achieving the objectives of the socialization of environmental management and community empowerment;

3. The ability of participants to grow creative products and produce products.

The target participants had previously planned to reach 25 people. In this activity the number of participants who attended was 25 people. Achieved number of participants reached $100 \%$ of the planned target. This figure shows that PPM activities seen from the number of participants can be said to be successful. The achievement of the objectives of environmental management socialization and community empowerment in developing tourism potential in the sedau environment, namely the Batu Burung beach, is generally good. All participants in this activity are very interactive and follow the event to the end. The results of environmental management and community empowerment in the form of public awareness of the importance of a clean and neat environmental arrangement by starting to provide trash bins and signposts for beaches around the road to the stone bird beach by using three different languages, namely Indonesian, Arabic Malay and Mandarin, so that more seen and known by people outside the Sedau community. Overall this activity can be said to be successful. The benefits obtained are public awareness about the environment of clean tourist objects and awareness to promote tourism objects in the surrounding environment to be better known by the wider community. 
Hopefully this activity can contribute to the community as one of the applications of the Higher Education Tri Dharma in particular community service.

\section{CONCLUSION AND SUGGESTION}

\section{Conclusions}

Public awareness in developing and managing the tourism potential that is around it is very necessary to be developed, so that tourism objects, especially Batu Burung Beach can be widely known by people outside the district of Sedau. If there is no awareness from the community in developing this tourism potential it will be very detrimental to the local community because the potential of this beach is very unique.

For this reason, there is a need for socialization activities on environmental management and community empowerment in the development of tourism potential in Sedau Subdistrict, South Singkawang District. Socialization activities on socialization activities on environmental management and community empowerment in developing tourism potential in order to raise community awareness around the Batu Burung coast to manage beaches neatly clean and promote it so that the attractions of this stone bird can be known by the wider community

\section{Suggestions}

In writing this report, the author has several expectations, namely:

1. It is expected that this activity can help to widely introduce the tourism potential in the Sedau environment, South Singkawang District.

2. It is expected that this activity can be continued by other community service teams in different places.

\section{ACKNOWLEDGMENTS}

Acknowledgments are addressed to STKIP Singkawang for facilitating this PPM activity so that this activity runs smoothly. And also to the Sedau Village Chief, PKK Mobilization Team, the RT Head and the community of Sedau Village for their participation in this activity.

\section{REFERENCES}

https://bappeda.kalbarprov.go.id/documents/perda-no-2-tahun-2019-ttg-rpjmd-tahun-2018-2023//

Noor, M. (2011). Community development. CIVIS Scientific Journal, 1 (2), 87-95.

Prihartono, S., (2013). Strategies for Empowering the Poor in Increasing Income. Journal of Non Formal Education and Community Empowerment, 2 (2), 15-21

Suharto, E., (2010). Building Communities Empowering People. Bandung: Aditama

Sujali, (1989). Tourism and Tourism Geography. Yogyakarta: Faculty of Geography, Gajah Mada University. 